\title{
Dielectric Properties of Al-Nb Amorphous Mixed Oxides
}

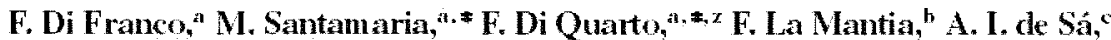 \\ and C. M. Rangel
}

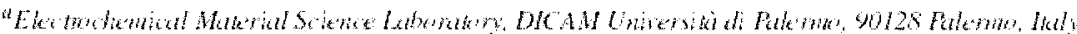

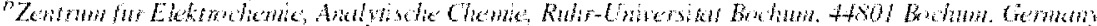

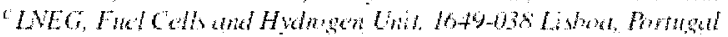

\begin{abstract}
An impedance study of amofphous thin oxide films grown on sputtered Al-Nb alloys is presented. The charicterization of the eketronic properties of mixed amorphous ox de on the basis of the theory of amorphous semiconductor Schotky barrier has been carried out for anodic filin on AL-92at. FNb in a very detaikd manner. The semiconductor to insulator transition of formed oxides as a function of the alloy compostion at taxed finat voltage bas baen supported by differential admithance study. A possible rationale for this transition has been suggested taking thto account the changes of solid state properties optical bandgap and electronic structur of the films derived from the tithing of the differential admittance curves al different frequenctes.

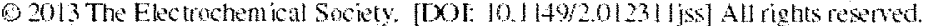

Manusoript subnitied April 17, 2013, revised manuscript recened July 29. 2013. Published August 21. 2013.

In ordes to satisly the requiremen of miniaturization in modern linear integrated circuits. electronic components are developing to ward smaller rolume. For electrolytic capectors this issue can be acheved by intersing the specific capatance, i, e. by increasing the de lectric constant and the woughess factor. $\mathrm{Al}_{2} \mathrm{O}_{3}$ is a wide bandgap. $\mathrm{E}_{\mathrm{z}}$. msulator with an amphorenc eharocer. whely employed as dielectno in electrolyte capacitors $(\varepsilon \sim 9)$. I can be drectly grown on Al metal by anodizne and an eas electothemed etching process allows to increase the spectic sudace of the metal.

$\mathrm{Nb}_{2} \mathrm{O}_{5}$ is a n-type semuconductor with relaturely lower bendgap $\left(E_{y} \approx 3.30 \pm 0.1 \mathrm{eV}\right)^{23}$ and chemically stable in a wide range of $\mathrm{pH}$. A rery high. held dependent, dielectric constant $(\varepsilon-53)^{2}+$ is reported for anodic niobia, which makes this oxide a very appealing high $\mathrm{k}$ material. even if the possibility to the $\mathrm{Nb}_{2} \mathrm{O}_{5}$ as delectric is limited by ils poer bleking chateder.

In Rets. 5-7 the use of ithemically prepared $\mathrm{Al}_{2} \mathrm{O}_{3} \mathrm{Nb}_{2} \mathrm{O}_{5} \mathrm{com}$ posite oxides is suggested as a vable route bincrease the dielectro constant with respect to that of pure alumina. This eflect is also ob served for Al-Nb mixed oxides grown by andizing sputter deposted Al-Nb alloys." An increase in the dielectic constant up to -22 is reputed for andic thms grown on Al-4at. $\% \mathrm{Nb}$, which was the $\mathrm{Nb}$ nchest invesligated alloy.

In a recent work" we have shoun how it is possible to tailon kindgap. Hathand potental and whano in-ype semconductor or insulater of Al Nb mixed oxides. pepared by ancolizng sputering depowited $\mathrm{Al} \mathrm{Nb}$ alloys cowering all the composition range between pure $\mathrm{Al}$ and $\mathrm{Nh}$. In this wok the effect of $\mathrm{AlN}$ b ratio in determin ing their dielowis and electionte properties was studed by means of toh electrohemital impedance spectoscopy (EIS) and diferen thal admitane DA meastements. The dependene of admitlance components for the No richest investigated alloy will be discussed quantitatively on the bisis of the amorphous Sehotky barner thery.

\section{Experimental}

Al Nb alloss were deposited by magnetron sputteng using sto Alom Tech Ltd system, with targets of aluminum $(99.990 \%)$ and no bium $199.9 \%$. Sputering was pertomed in $5 \times 10^{-3}$ mbar argon after previous evacution to $5 \times 10^{-7}$ mbar. The substates consisted of high purty aluminum shee that had ben electropolished for 180 8 at $20 \mathrm{~V}$ in a solution of ethand and perchlore acid $(4: 1$ by vol. at $283 \mathrm{~K}$. Al. Nb and Al-Nb alloys contaning 9. 40.55,66,81 and 92 at. nowium have hen obaned. aconding to Ruthertod Back

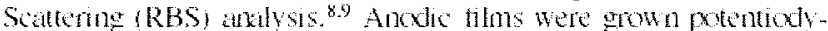
namically to $9 \mathrm{~V}$ is. $\mathrm{Ag} / \mathrm{AgCl}$ (silver/silver chlonde: $0.198 \mathrm{~V}$ is SHE on all the inestiated allors at $100 \mathrm{mV} \mathrm{s}^{-1}+00.1 \mathrm{M}$ ammonum biborate $(\mathrm{ABE})(\mathrm{BH} \sim 8.5)$, whe boh $\mathrm{ALO}_{3}$ and $\mathrm{Nb}_{2} \mathrm{O}_{5}$ arc

EElectrothemical Society Active Menber.

"F-mail: francescodigteartokumipa it repred to be themedy namially stable according to the Pourbax s diagrams relative $10 \mathrm{Al} \mathrm{H}_{2} \mathrm{O}$ and $\mathrm{Nb} \mathrm{H}_{2} \mathrm{O}$ al rom lemperature,

Electrobemical impedince spectroseoy (EIS) data for andized alloys were obatind using a Parstal 2263 (PAR), controlled by acom puter viat Electrohemstry PowerSuite sotware. A thee-eletnok arringement was thed. consistng of the anodred specmen, a reterence eletrode (silver/silver chlonde) and a Pl net having a very high specille area immersed in $0.2 \mathrm{M} \mathrm{Na}_{2} \mathrm{HPO}_{+}$. The umpedance spectrat were generated by applyng a smusedal signal of amplutude $10 \mathrm{mV}$ oner the trequency range $0,1 \mathrm{~Hz}-100 \mathrm{kHz}$. The resultant spetra were analyzed with Zview soltware

\section{Results and Discussion}

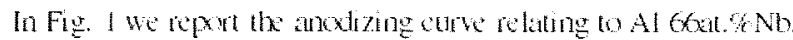
As typeal of valve metals, aher an inthal inerease the curron don sity reaches an almost constant value which remains unchanged up w the seketed final formation voltage: it is improtant to stress that the chare densily increases linearly with the potential dumg the an-

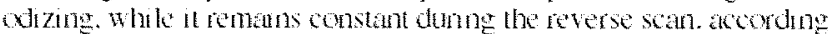
to the theory of high tield growth mechansm tor valve metals. As expected to anolic burrer oxides a very low curren density is measured in the reverse sean. de the fomaton of a bloxking tim. From

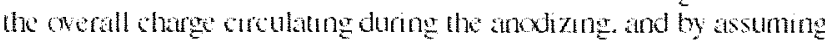
tor the oxide dersity and molecular weight the values obtaned by arcraging the density $p$. and moleculat weight. MW. of the pure oxides. it was possible 6 roughly estimate the film thickness. as shown in Table I. An AlNb ratio into the oxide concident with that of the base alloy was asumed in agrement with prevous results reported in the likerture. bused on Ruthertord Back Scattering analysts of the anctic film compostion. ${ }^{x y}$ The estimated values compare well with

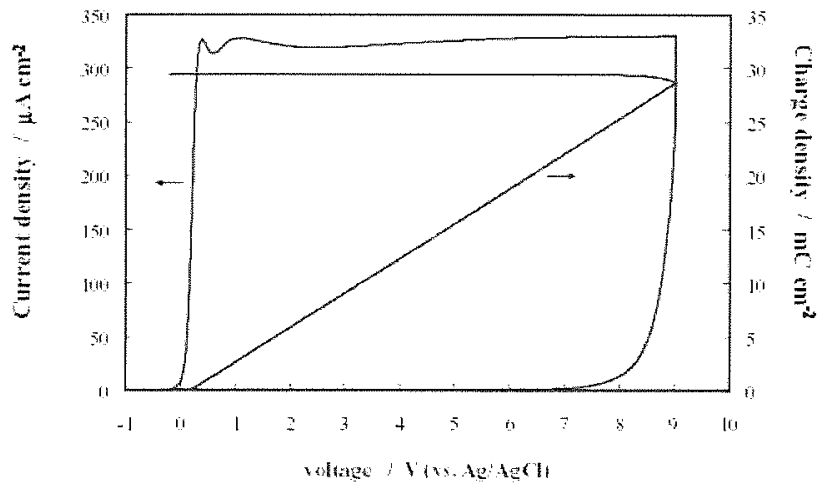

Figure 1. Current density and charge density es potential cures recorded

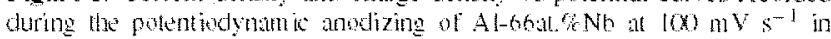
$0.1 \mathrm{MABE}$ 